Natural Hazards and Earth System Sciences (2004) 4: 449-462

SRef-ID: 1684-9981/nhess/2004-4-449

(C) European Geosciences Union 2004

Natural Hazards and Earth System Sciences

\title{
Review of retrofit strategies decision system in historic perspective
}

\author{
M. D. Bostenaru Dan \\ Institute for Technology and Management in Construction, Am Fasanengarten, Geb. 50.31, University of Karlsruhe, D-76128 \\ Karlsruhe, Germany
}

Received: 30 March 2004 - Revised: 22 April 2004 - Accepted: 6 June 2004 - Published: 25 June 2004

\begin{abstract}
Urban development is a process. In structuring and developing its phases different actors are implied, who act under different, sometimes opposite, dynamic conditions and within different reference systems. This paper aims to explore the contribution of participatism to disaster mitigation, when this concerns earthquake impact on urban settlements, through the support provided to multi-criteria decision in matters of retrofit. The research broadness in field of decision making on one side and the lack of a specific model for the retrofit of existing buildings on another side led to an extensive review of the state of the art in related models to address the issue. Core idea in the selection of existing models has been the preoccupation for collaborative issues, in other words, the consideration for the different actors implied in the planning process. The historic perspective on participative planning models is made from the view of two generations of citizen implication. The first approaches focus on the participation of the building owner/inhabitant in the planning process of building construction. As current strategies building rehabilitation and selection from alternative retrofit strategies are presented. New developments include innovative models using the internet or spatial databases. The investigated participation approaches show, that participation and communication as a more comprehensive term are an old topic in the field politics-democratisation-urbanism. In all cases it can be talked of "successful learning processes", of the improvement of the level of the professional debate. More than 30 years history of participation marked a transition in understanding the concept: from participation, based on a central decision process leading to a solution controlled and steered by the political-administrative system, to communication, characterised by simultaneous decision processes taking place outside politics and administration in cooperative procedures.
\end{abstract}

\section{Introduction}

Retrofitting existing buildings is a risk mitigation measure against earthquake hazard impact on urban settlements. As in urban development the individual interest is often opposite to the collective interest, the private interest often opposite to the public interest and the local interest often opposite to the global interest, the urban planner stays, through his activity, middle in these interaction fields. Deficitary communication is to be overspanned through intermediary instances. The urban society builds a legal and an institutional framework respectively to control these relationships and to steer the development process. Thereby a non static model arises, the dynamic of which has become faster in the last years, as the number of actors grew and their motivations and expectations became more and more different. Co-operations come to expression in processes and in the behaviours of participating actors, up to dedicated organisations, which moderate the processes, bind action fields and support co-operation and innovation.

Recent years have seen a sustained research in the field of decision making. Malczewski has provided in 1999 an extensive state-of-the-art review of current solutions for a problem coming closest to that stated in this paper, namely multi-criteria decision systems for spatial situations. However, due to the particularities of geographical information systems, the format of spatial systems addressed in the review of Malczewski (1999) differs from that used in retrofit design and implementation.

A completely different approach is to look at case studies of successful solutions rather than at generalisable techniques. This approach was followed in an individual study of the author on sociology of architecture from 1998, in a seminar advised by B. Schäfers, who later summarised the conclusions from the seminar series in a book on the same topic (Schäfers, 2003). 


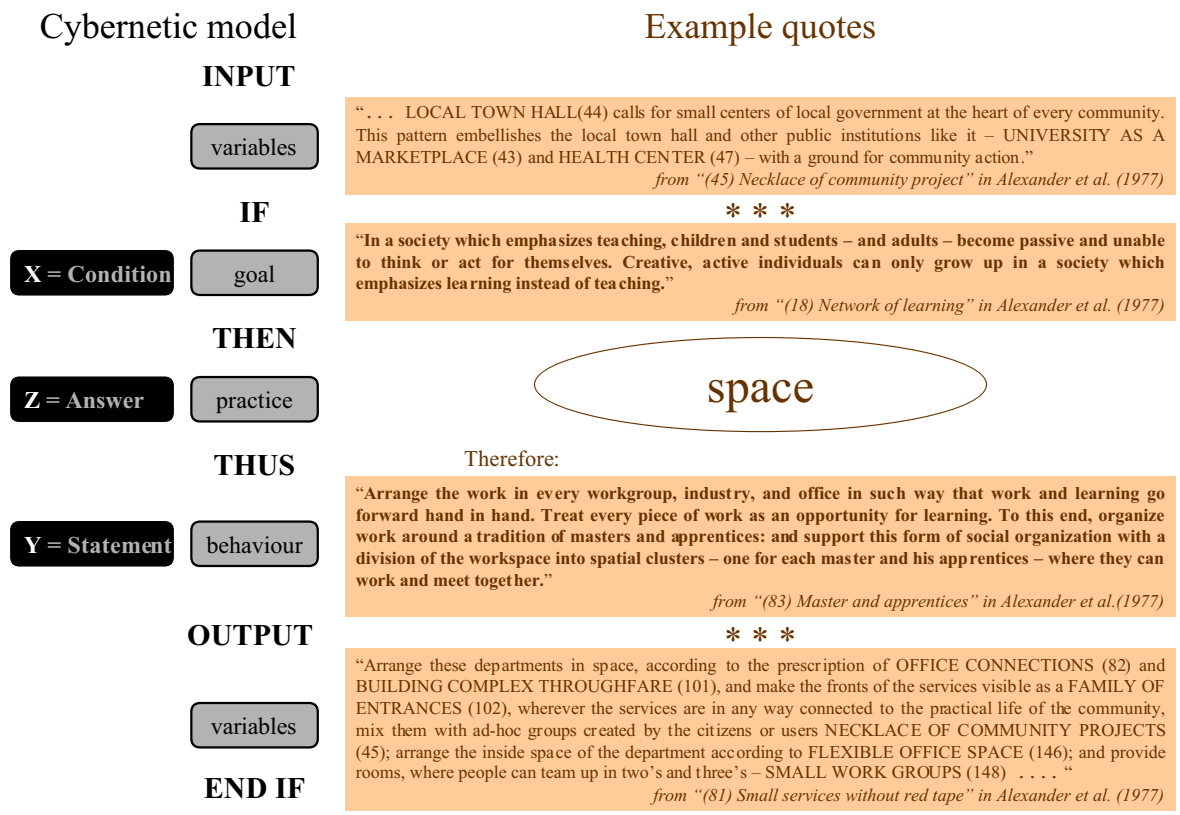

Fig. 1. Formulation of the "pattern language" (Alexander et al., 1977) cybernetic model. On the left side the working model and then its cybernetic expression are vertically arrayed in two columns. On the right side quotations from various patterns are exemplifying the format in which the cybernetic language elements are expressed in Alexander's (1977) work.

This paper follows the second approach mentioned above and thus performs a comparative analysis on decision model examples which address participative issues. Participation means co-decision in planning processes designed by others. Central elements of the concept are influence, interaction and information exchange. Aim of this paper is to investigate the development over time in degrees of activation of those potentially involved in the implementation of retrofit techniques. Roughly it can be said, that since 1960 each decade contributed to the formation of one activity layer like information, participation, co-ordination and co-operation, which define together the communication process. The approach in this work deems that the different actors implied in retrofit design process need a common language to communicate. It is the scope of the paper to identify which kind of language would be the most adequate to perform an enhancement in the acceptance of measures towards the reduction of seismic risk.

\section{Historical approaches}

In the 60s' and the 70s' theory a closed model of planning was employed, in which the planning subject disposed of all information and power means to create a new world out of a "tabula-rasa"-situation (Häußermann and Siebel, 1993). The model suited the theme of the time: urban extension through satellite towns on the town edge. Intervention-administration and adaptation describe the image of the planning. Participation attempts were isolated cases (empirical single experiences like Byker in Newcastle, United Kingdom; see Amery,
1974), or single theoretical contributions (like the Pattern Language model by Alexander, 1977). The emancipation wish went over from the students movement to aesthetics and requested co-determination in construction. A new role of the architects outlined.

At the begin of the 70s the planning focus shifted towards conversion of city zones, where the planner had to mind numerous actors, uses, constructions. A new, "open", planning model was looked for, with somehow the same enthusiasm the architects of previous centuries were looking for a new style. An important contribution to the development of the participation models had the Stichting Architects Research-approach from Netherlands (Habraken, 1968) through the proposal of a method exemplified by the theoretical-methodological contribution of O. Uhl in Austria. Performance-administration and urban offer complete the image of the planning of this time. The autonomous architecture still co-existed with the newly developed model, but a new image of professionalism in architecture took shape.

\subsection{The 60s: the "pattern language" of C. Alexander}

C. Alexander developed in 1967 the model of the "Pattern Language" (Alexander et al., 1977), an action orientated approach, which means that the participative concern shall be fulfilled each time through the direct activity of the affected people (Bohning, 1981). A key for coping with environmental problems is given by Alexander (1977) in the participation of individual citizens using an architecture language, build on the basis of singular "words", which describe the typical space-configuring elements of settlements, buildings 
and constructive elements. Citizens should be first sensitised to environmental questions, could then participate to discussions about the configuration of the environment on the basis of "Pattern Language" and finally deal with the environment creating new "patterns". Bohning (1981) notes that Alexander imagined as communication basis utopically cultural education and creativity of all.

The essential features of the spatial and social organisation of a complex planning artefact consist of elements (the "patterns") and their combination rules. Basic prototypes are defined in each case through a morphological (spatial) and an anthropological (functional) factors in 273 cybernetic models called "patterns". A cybernetic model M of a system S is a system, which is equivalent to $\mathrm{S}$ in some standpoints but is easier to understand than S. It can be talked about such a model when there are at least three systems (Fig. 1): a system to be elucidated (an impressive space situation $\mathrm{X}$ ), a known system (a typical architectural arrangement $Z$ ) and a system to be discussed (the pattern Y). The building of patterns is helped in two directions. On each pattern some are growing while other help organising larger patterns. The "patterns" build then the vocabulary of an architectural project, through which the planning process of a construction task was structurable in advance and could be thus brought about to the general public.

Alexander's theoretical approach was widely recognised, but "Pattern Language" was scarcely applied in the practice. Objectivity was missing in the presentation of individual patterns, which were stamped by the design style of the author. The participative function of the "Pattern Language" played a central role in the next projects of Alexander and partners. It can be recognised in the newest developments, that "building box" principles follow a similar logic. It can be also observed that patterns defined by Alexander (1977) like green streets to avoid sealing, open water in the middle of congested urban areas, new concepts for transportation, children friendly in-playable towns and also maintaining the siedlung identity through gates marking entrances belong to the trigger impulses of the IBA Emscher Park (IBA, 1999). These examples belong to participation approaches of another generation and correspondingly such a language was to be brought over to the participants in another way.

\subsection{The 70s: S.A.R. method and O. Uhl}

O. Uhl had been concerned with the questions of industrialised construction since the 50s. Uhl criticised the functionally determined architecture and saw amelioration of the built environment in that of the processes about the building. "The openness of production means and construction forms shall make possible and support emancipatory processes and socio-cultural skills" (Fingerhuth and Koch, 1996). Ottokar Uhl aimed at a democratisation of aesthetics by introducing participation in the planning process for social housing. The utility value should be co-realised by a residence user enabled for learning in an easily changeable environment. Procedurally determined architecture, with permanent change- ability of the needs in both project and use phases, gives primacy to feedback and implicitly learning processes with running ameliorations. Uhl employed the S.A.R. method for professionalisation, to measure the achieved degree of participation. It was an object orientated approach, with the accent on how to create premises for participation in construction, independently from the social and psychical conditions (Bohning, 1981).

"Wohnen morgen" (=Housing tomorrow) was a winning competition project, a first stage of which was realised as demonstrative social housing project by the architects $\mathrm{O}$. Uhl and J. Weber, and the sociologist R. Dirisamer between 1973 and 1976 on the town edge of Hollabrunn, Austria. Use of the S.A.R. method provided the spatial principle of a load bearing scaffold (columns, beams, slabs and staircases) optimised regarding the urban situation (where participation was impeded through provisions of the property developer), the variety of residences, the soil quality, the building costs and the construction time. The structure could be "filled" (Fig. 2) with modifiable flats with "the goal to delegate the decision about the kind of the housing to the panels participating in Hollabrunn and last but not least to the future housing user" (Bohning, 1981). Different from the usual client relationship between residence user and planer, co-operative planning actions between "affected people" (term used by Uhl in Hempel and Uhl, 1982) and "experts" of different disciplines were employed to solve complex planning tasks. Decisions and premises for later decisions, when anticipated and demanded changes in living conditions occur, are seen as part of the planning (Fig. 2). Then, since people still live there, the planning process in Hollabrunn is not concluded till today.

The discrepancy between the ideal aspired at and the reality in technical construction (limited flexibility) and in participative (only half of the future user were reached) field limited the Hollabrunn case (Bohning, 1981). It marks nevertheless the step from single project to construction research through studies that accompanied the planning experiment: a sociological one (systematic documentation and analysis), a technical construction one (possibilities of individualised residences with standardised fabrication), and a technicaleconomical one (fabrication and running costs efficiency). The flexibility of a "primary structure" with elements "of second order" was later used in the "House of the flexible inhabitants" in Linz-Haselgraben, Austria, by architects $\mathrm{H}$. Frohnwieser, H. Pammer, E. Telesko and H. Wertgartner and in "t'Karregat", Eindhoven, the Netherlands, by van Klingeren (Freisizer et al., 1987).

\section{Current strategies}

Incrementalismus (Häußermann and Siebel, 1993) is an open model developed in the $80 \mathrm{~s}$, in which the planning is dissolved into small steps. In one of its forms, the strategic planning, the means for reaching the planning aims are distributed between different planning layers and time horizons 


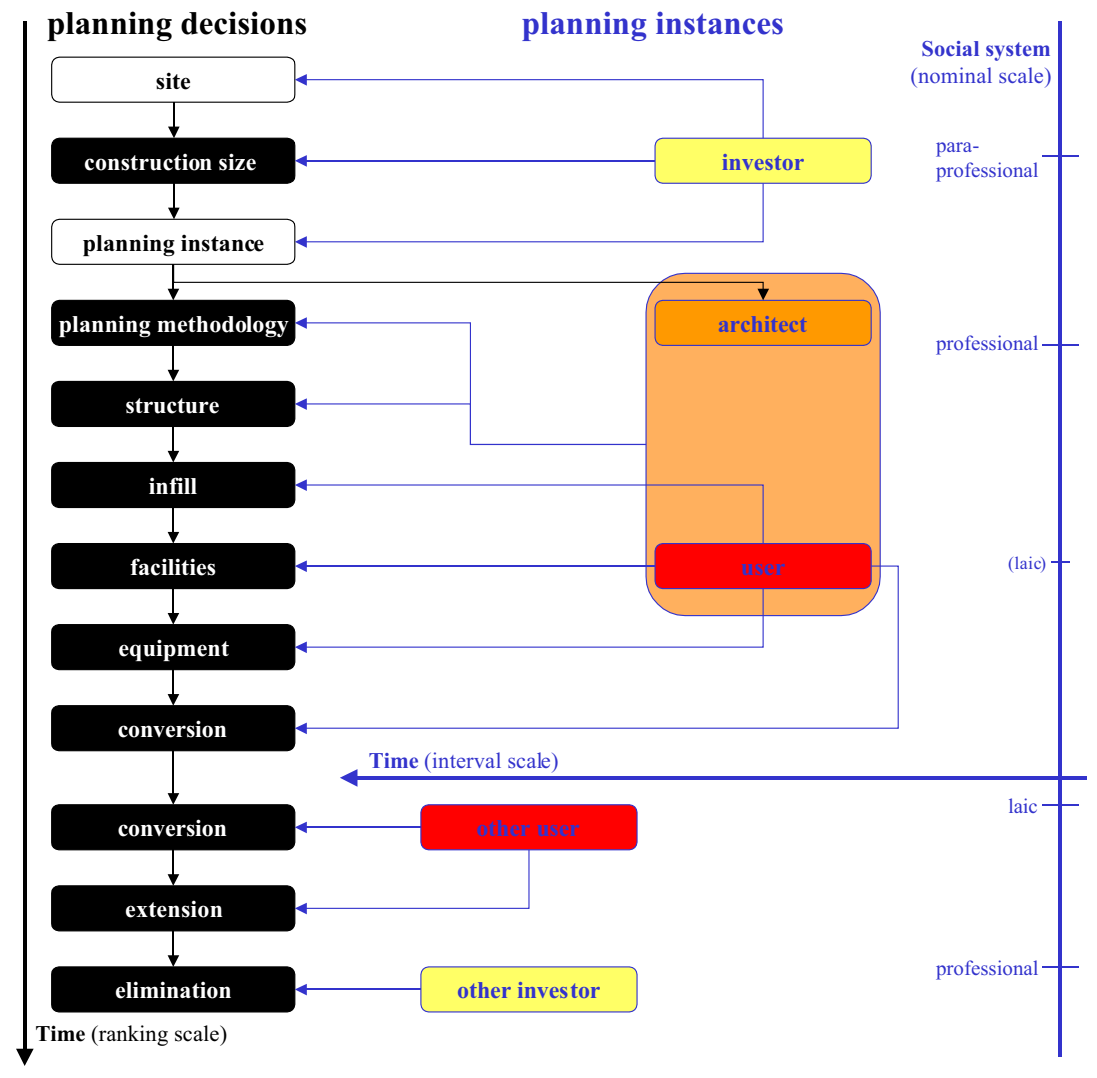

Fig. 2. Dimensions of the decision process in Ottokar Uhl's project "Housing Tomorrow" in Hollabrunn, Austria. The column on the left side shows the so-called "planning decisions" in their time succession, based on a scheme in the publication by Hempel and Uhl (1982). The right column shows the so-called "planning instances". Additionally to the connections between the elements on the two dimensions of the decision process, which were also shown in the original scheme, this figure shows an interpretation of this dimension regarding scales their scale and cross-relationships.

and realised through different kinds of plans, different means of visualisation and of consensus formation. Within strategic planning innovation is always possible. The theme focus laid on the urban revitalisation and attracted through key projects the interest of important actors, who are staying in foreground in PPP (co-operation of the public administration with private actors, see Heinz, 1993).

In the 90s towns were grown to complex metropolis, whose problems were solved predominantly through the already tried out models of PPP and of strategical planning (Fassbinder, 1993). Innovation through strategic planning has been tried out in case of the GrünGürtel (GreenBelt) Frankfurt on the Maine, Germany, in a project year to create an image of the free space: symbol of green on the town ridge (Koenigs, 1993). Communication reached out over the offer-participation and found expression in the planning process through proceduralism, problem solving and simultaneous decision processes. The planers' role changed: they became intermediary between state, market and inhabitants (Selle, 1994).

\subsection{The 80s: rehabilitation of the building stock}

The extent of the co-determination zone won complexity: from the immediate living surroundings up to the wide landscape, on the town periphery. In order to be able to cope with environmental problems, a corresponding refreshment of the democratisation approaches in planning became necessary. Citizens could co-determine in local partnerships (co-operation of the public administration with neighbourhoods on site, Behringer, 1993). These were acting in theme fields like improvement of the living surroundings (Zürich, Switzerland, see Selle, 1994), neighbourhood support in town modernisation zones (Vienna, Austria, see Leichtle, 1993), co-operation nets for the improvement of discriminated town zones (Bremen, Germany, see Lürssen and Richters, 1994), building restoration and infrastructure for active work. In all cases it was a matter of stimulating social nets.

Rehabilitation spans in the conflict area between conservation of historic buildings, construction technique, construction costs and user interests. One of the tasks in the rehabilitation in Stuttgart Weissenhof, Germany was to balance concurring goals and interests to a sensefull solution 


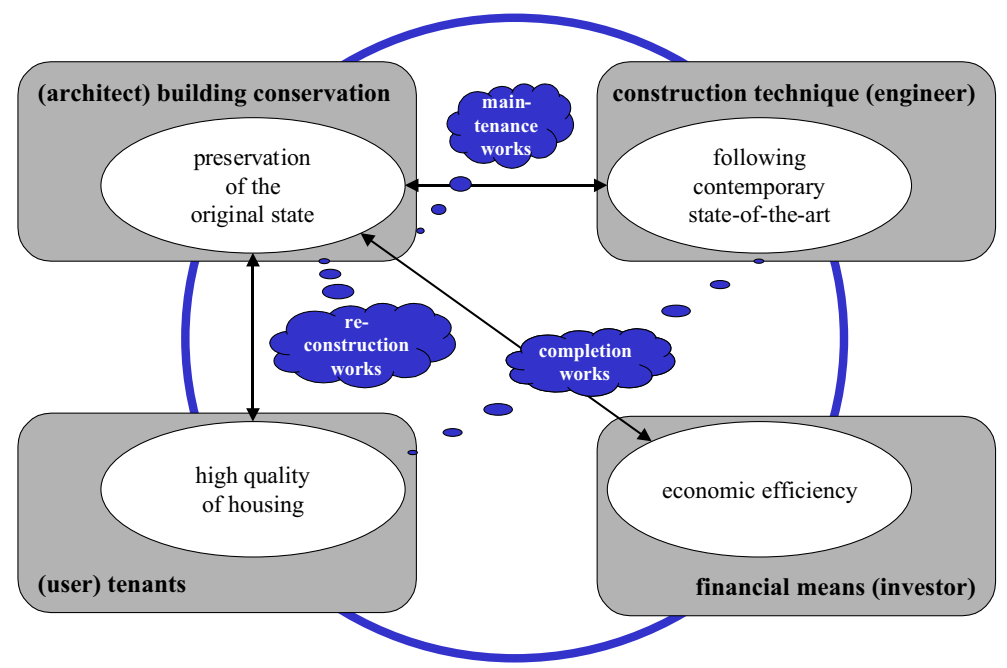

Fig. 3. Interest groups around rehabilitation works, an overview of the goals, conflicts, and preferences for various kind of works of the actors involved in decision making, based on the description given by Nägele (1992).

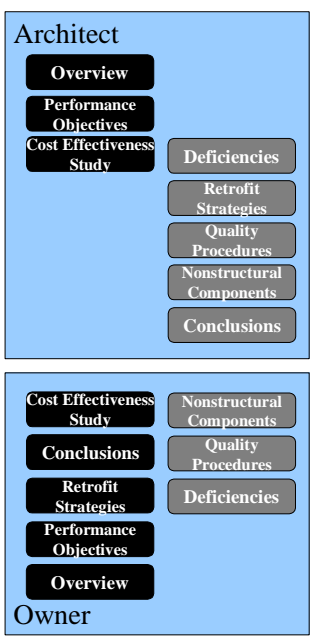

(a)

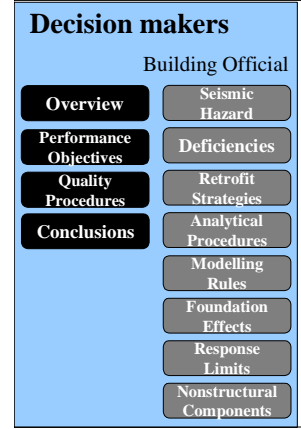

(c)
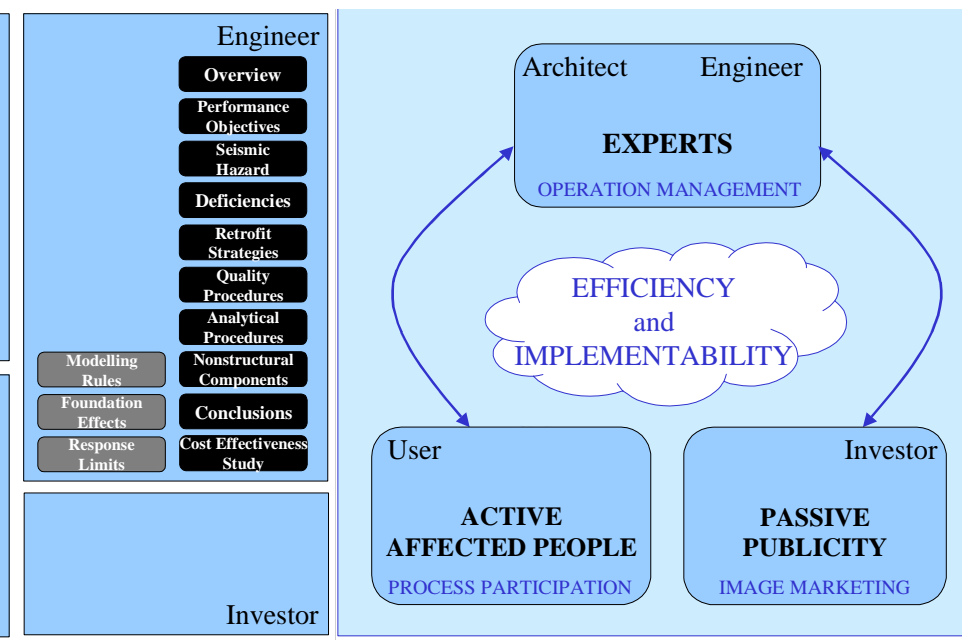

(b)
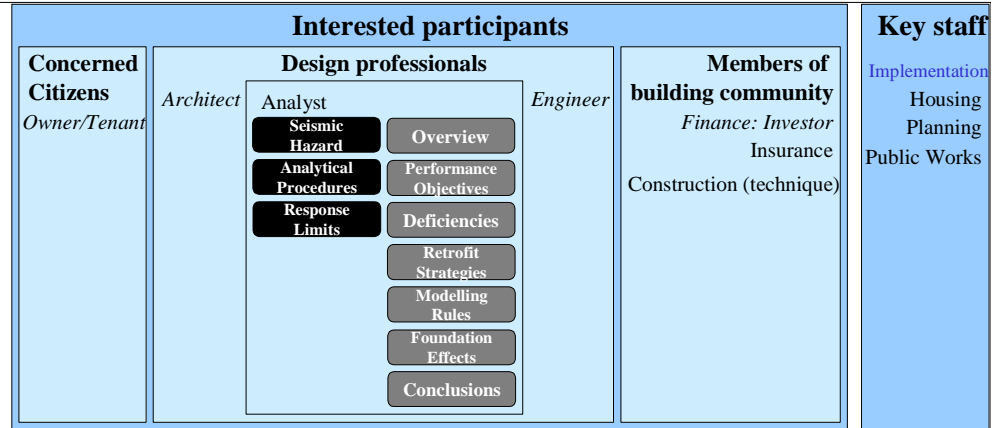

Fig. 4. Audience spectrum for seismic evaluation and retrofit, a combined view from ATC (1996), FEMA (1989) and the author's doctorate research: (a) Importance for the four actors in the author's decision model (each a blue rectangle), as considered in ATC (1996). Chapters of primary interest are white on black, chapters of secondary interest are white on grey, chapters of limited interest are not mentioned at the respective actors; (b) Actors considered in the author's decision model; (c) Importance for other actors taken into consideration in ATC (1996), building official and analyst, embedded into the categories enumerated in FEMA (1989), on rectangles in blue tones. Importance of chapters is symbolised as at (a). 


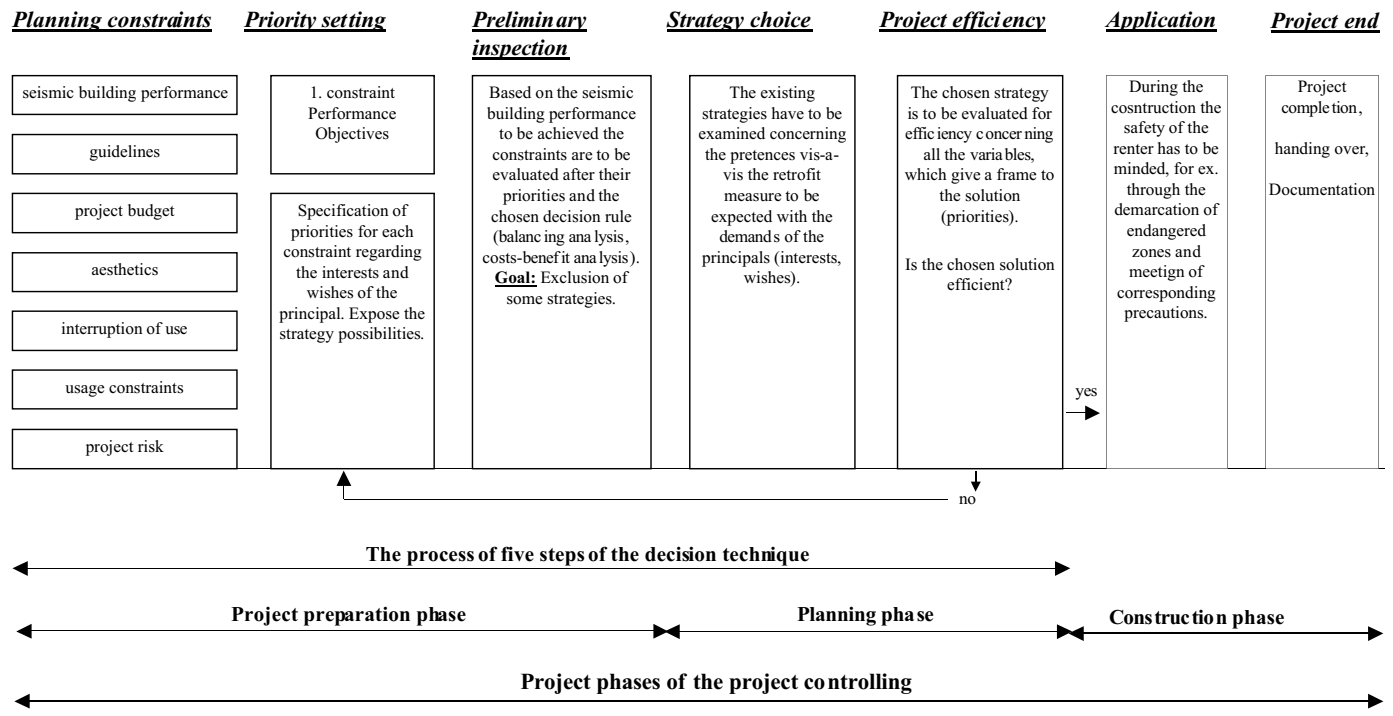

Fig. 5. Application flow of decision technique. It can be seen which steps of the multi-criteria decision making take place in which phases of project controlling (along the second line). The first column details what kind of constrains influence priority setting. Preferences expressed in criteria of the actors "engineer", "architect", "investor", "architect", "user", "user"/"investor", "investor" are exemplified (from top to bottom) as concurring goals, those potentiating each other being omitted. To be noted is the feedback from the last stage of the decision technique (single criterion) to the first stage (multi-criteria). (This graphic is based on the German version of the same from the diploma work of Gülay Öztürk, a student advised by the author in 2002/2003).

(Nägele, 1992). In Fig. 3 the concerns, the interest conflicts and the kind of works defined in order to mark the limit between these interests are shown. The preferences of specific interest groups for a certain kind of work are thereby highlighted. The decision process at the rehabilitation of the Weissenhof Siedlung was visualised by Nägele (1992) in a decision table including examples of "maintained", of "reconstructed" and of "completed"/renewed building elements. For each a construction measure is described, followed by a yes/no/neutral statement from the point of view of the actors respectively, and finally by the decision. Thus in an example of maintenance the decision problem was if the load bearing iron and iron skeleton constructions of the houses of Le Corbusier and Mies van der Rohe should be maintained. As from the criterion "conservation" and the criterion "costs" the answer was yes and from the other two neutral, the decision was to maintain them. None of the goals was implemented recklessly against the others. Instead, the goal conflict was analysed, subdivided and then the agreeing parts were set together. Nägele (1992) calls this conflictoptimisation process. Sometimes, when one of the restoration goals was reached, another one went lost.

\subsection{The 90s: ATC-40 approach}

According to the report on "Seismic evaluation and retrofit of concrete structures" (ATC, 1996), retrofit strategies, retrofit systems and design constraints build the ingredients with which a retrofit decision has to be met. Retrofit systems are specific constructive measures to implement technical strategies through changes in the strength, the stiffness and/or the ductility of a building. On the opposite, design constraints are of concern for management strategies, as they are defined as factors, other than the structural characteristics, that affect the applicability of a given retrofit strategy. Each chapter is written for a broader or narrower range of expected audience comprising building owners and agency representatives, architects and building officials as well as structural engineers and analysts (Fig. 4), and the appropriate level of interest, assessed by the authors, is presented in a bar on its title page.

Figure 5 shows the five steps retrofit strategy process in decision making during the controlling phases of project preparation and respectively implementation. Multi-criteria decision involving actors participating in the retrofit process takes place in the early stages of project preparation phase and planning phase. In a first inspection phase unviable alternatives are excluded from the decision making procedure. Here the building performance is the eliminatory constraint. Constraints depending on the preferences of various actors influence the priority setting. Priorities are set depending on constraints and the performance objectives. Two "decision" tables are proposed to be employed. The first contains a checklist of retrofit design considerations, comprising constrains, importance scores and limitations. The second is a strategy evaluation matrix, comprising strategy variants and recommended systems to reach them. The merits of the strategies, which measure their desirability, are not coincident with the constraints. A total score is computed in order to determine viable solutions. The final check regards the efficiency of the strategy. Decision aspects are less relevant in the construction phase. Merely at project end documentation of employed techniques is required. 


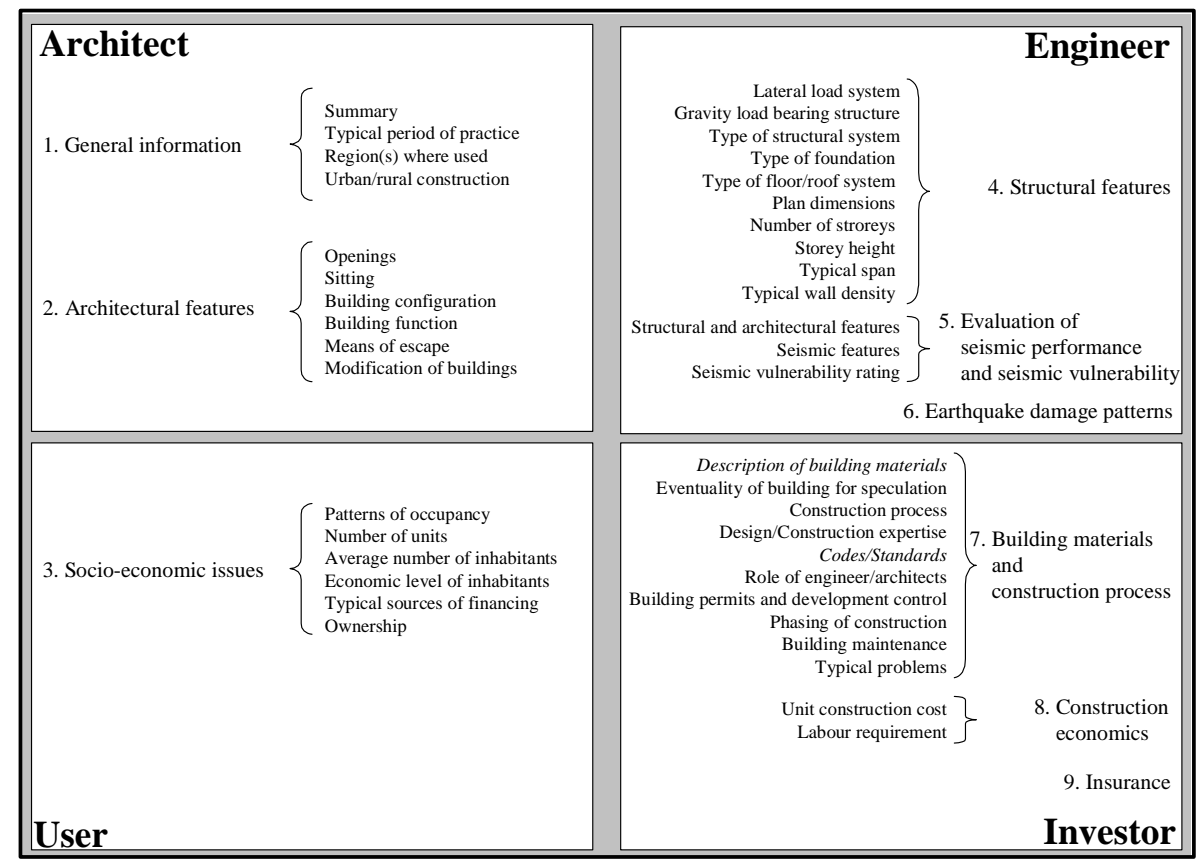

(a)

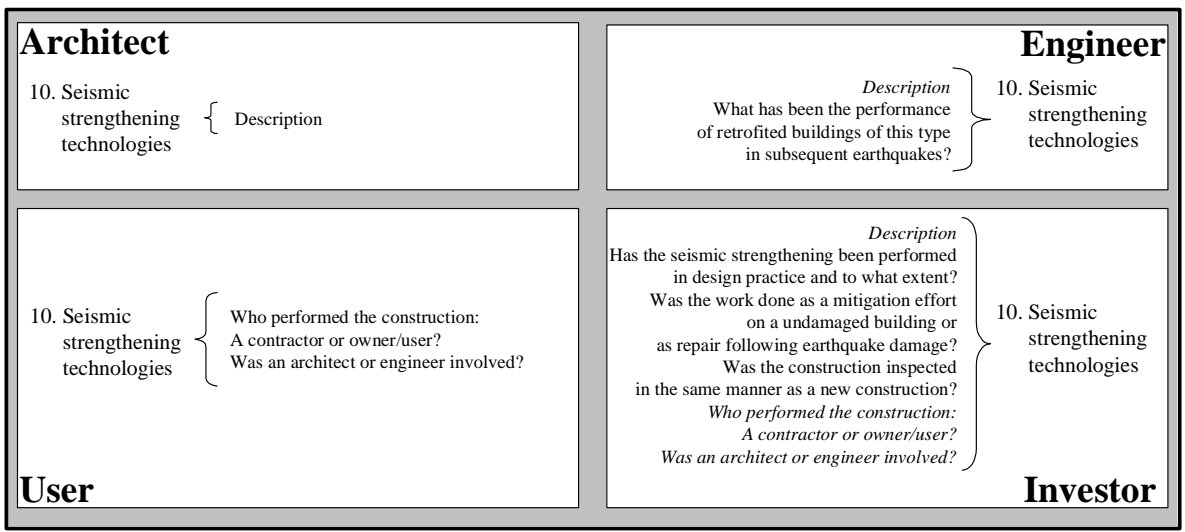

(b)

Fig. 6. Chapters and questions in a standard World Housing Encyclopedia (EERI, 2004) form, grouped after the relevance as priority criteria for actors involved in the decision on retrofitting existing buildings: (a) for the building as such; (b) for a retrofit measure on an existing building. Text written in italics marks criteria common to more actors.

A new and interesting application related to this type of approach is that of the Stadtforum Berlin (the town-forum Berlin, Germany, see Selle, 1994), a new edition of the citizen forums in the 70s (the Munich Forum existed that time since 25 years, see Selle, 1996) in form of partnership teamwork beyond the limits of PPP, by directing the layers of publicity to the representatives of the urban society, the professional public and of the wide public.

\section{New developments}

Today a new model of planning becomes accepted along with a new task definition. This one is again in pioneer phase, unveiled by means of demonstrative projects. The new task is called Innovation. A "Planning through Projects" endeavour was developed as corresponding model.

An example mentioned in many cases, where this planning model was used, is the IBA (International Construction Exhibition) Emscher Park in Germany (IBA, 1999), where new tasks aroused for old industrial regions. No conversion in classical sense was possible, innovation was needed. Numerous communication forms were tried out in different projects accepted by the IBA. It was a matter of their networking, too: the transition from the one-point-participation to communication strategy. The strategy of the IBA set forth the theory of incrementalismus (IBA, 1991); new in the approach was that the projects had to generate the innovation potential themselves in order to become a better routine and avoid remaining the singular event of a construction exhibition (Selle, 1994). 


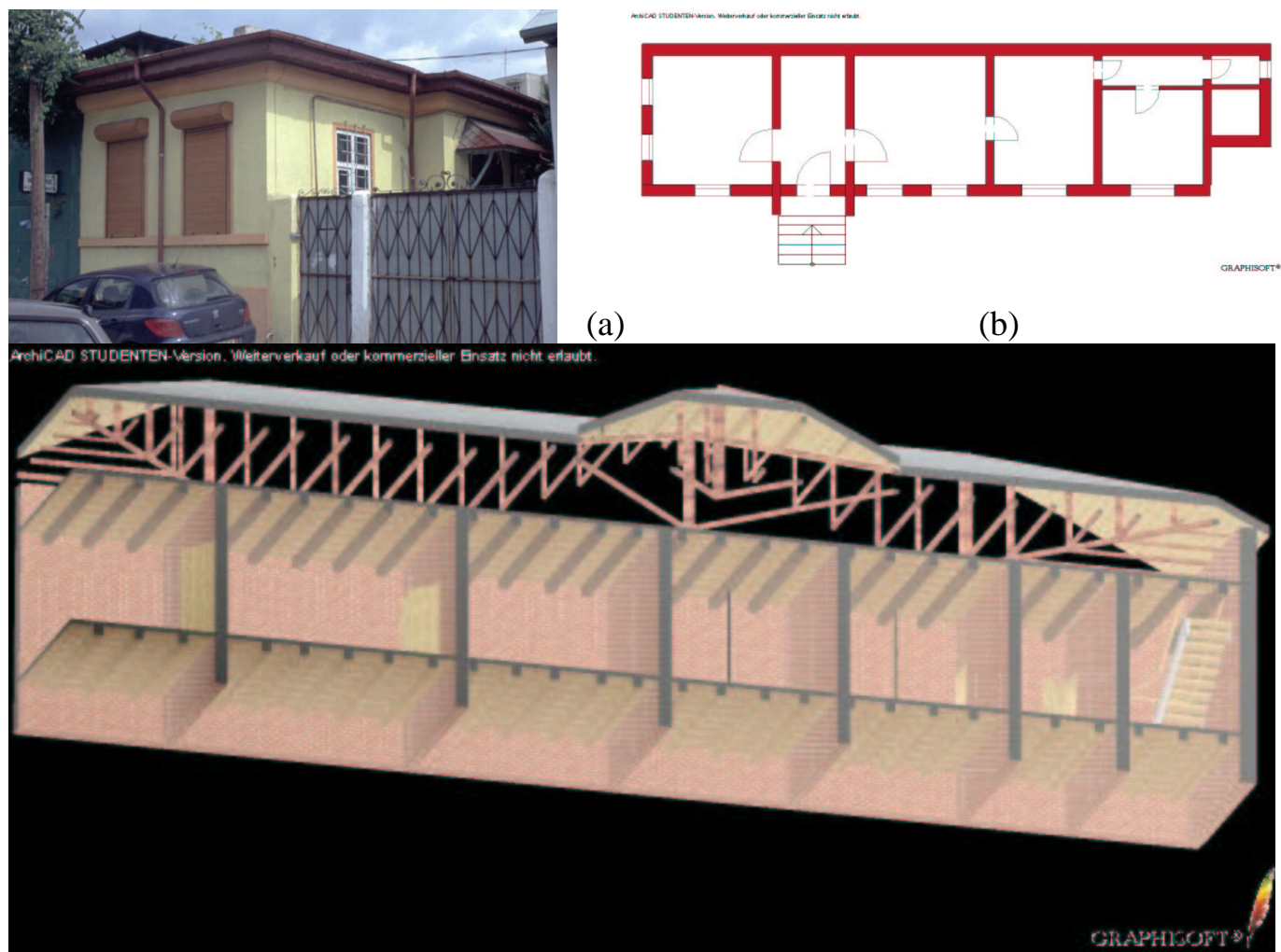

(c)

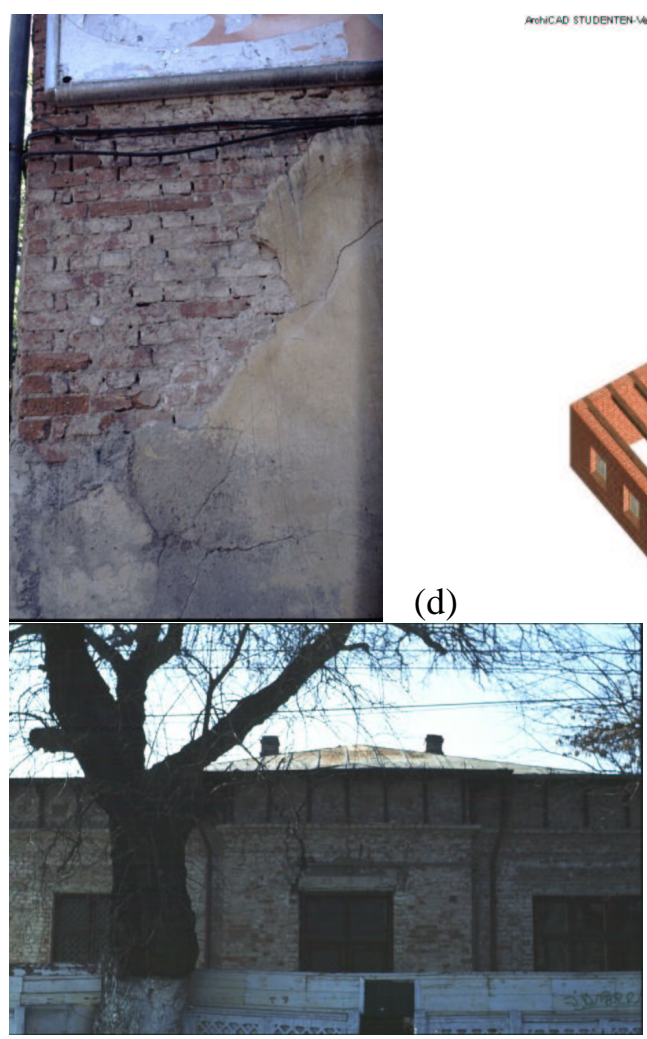

(f)

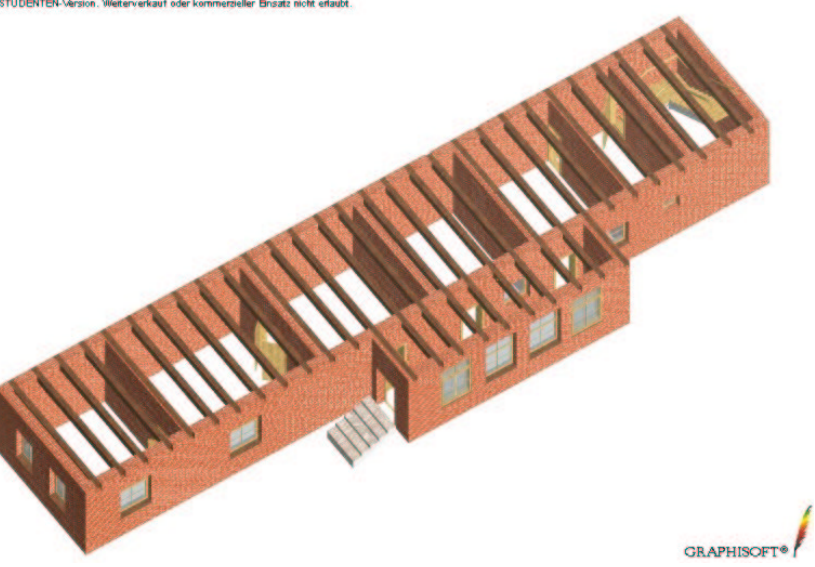

(e)

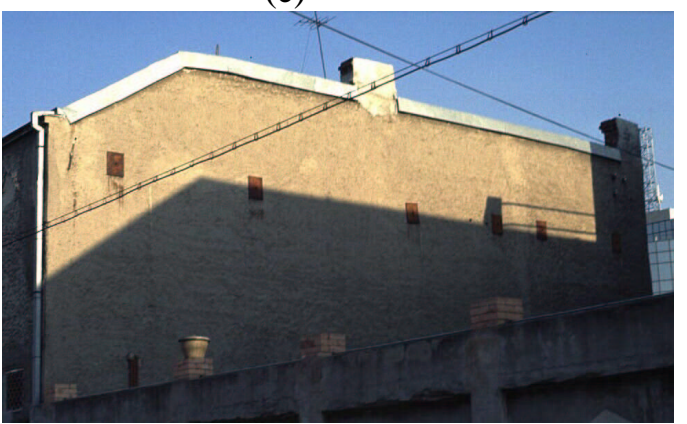

(g)

Fig. 7. Characteristic pictures for a typical World Housing Encyclopedia report on unreinforced masonry construction (EERI, 2004, report \#85). (a) Typical house of the construction type; (b) Plan of a typical building; (c) Key load-bearing elements; (d) Critical structural details; (e) Key seismic features and deficiencies; (f) Typical earthquake damage; (g) Illustration of seismic strengthening techniques. (Drawings with archiCAD® Student version). 


\subsection{Today: the EERI World Housing Encyclopedia}

An new example of co-operation, in virtual space, providing decision makers with figures on possible impact of seismic events, is a joint project of the Earthquake Engineering Research Institute and the International Association of Earthquake Engineering: an encyclopaedia of housing construction types around the world fully using the interactive possibilities of the internet (EERI, 2004). The purpose of this encyclopaedia is to enable sharing of information and experience on both vulnerable and earthquake resilient housing types between housing experts, engineers and architects. This example of co-operation outreaches the dialogue models of the second generation of participation in decision making.

A standard format allowing for a comprehensive global categorisation of housing construction types was developed. Contributions are compiled by the under laying software, and constitute together a database, searchable according to criteria based on the aspects covered by the forms. Relevant aspects from architectural and structural features, to socioeconomic aspects, construction process and materials, and insurance are included (Fig. 6). The characterisation is made through completing check-lists as well as more detailed description, of seismic deficiencies, earthquake resilient features, damage patterns and dedicated strengthening technologies. Text information is completed by photos and drawings (Fig. 7). Ideally the same criteria used for new buildings (Fig. 6a) would apply to the strengthening technologies. However, in this later case all relevant aspects are brought under one section (Fig. 6b).

Architectural features are taken into account in a limited way. The building configuration alone could have been subject of a separate score. Besides, this is not the core of the issues concerning the architect in an earthquake engineering problem. Historical aspects are of great importance (for example building materials, important for dating). Another important aspect are brand walls, which permit different retrofit measures, as they have no openings (Bostenaru, 2003b). Architectural, more precisely finishing details, are important for the structural diagnostic. Criteria of relevance for the engineer shall allow not just setting a score for that building type but also building models of typical constructions for computer simulations. Economic issues not regarded by the encyclopedia are the costs of retrofit measures. Not covered criteria for the inhabitant are the duration of the measure and, more important, the possibilities for participatism.

\subsection{Perspective: retrofit elements}

Within the doctorate work of the author the idea of retrofit elements has been developed. Starting point was the methodology of Neddermann (2000) for costs calculation in building restoration. In that approach Neddermann (2000) sets up the restoration works on a building out of own constructionable parts instead of single execution steps, as practised before. The so called "element of the existing building" ("Altbauele- ment" in German) consists of a numbered package containing general description as well as numbered descriptions of all the works necessary in order to build that element.

Subsequent mounting of structural elements within redesign, aiming retrofit, is a special form of rehabilitation of existing buildings (Bostenaru, 2001). Common to both is that the existing building and its state are the planning basis for all further measures. Secondly, a parallel can be established between two factors describing existing building restoration and endangered building retrofit respectively. The targeted performance level corresponds to the rehabilitation factor of a building to be restored while the earthquake peril degree builds an equivalent to the damage degree of a building needing restoration.

These two insights built the ingredients for the concept of "retrofit elements". With help of retrofit elements it is aimed to allow for an interdisciplinary approach to disaster management through building retrofit. In building engineering a similar approach is known under the name "integral planning" and means that issues of construction technique, economy and building physics are considered from early stages of planning, when the architecture project is made. The retrofit elements are a structuring entity bringing issues of project management, costs estimation and structural design into the early stage of building survey.

Buildings have been divided into spatial elements which are characteristic for the survey, present typical damages in case of an earthquake and are decisive for a better seismic behaviour in case of retrofitting (Fig. 8). Architectural and engineering characteristics, as well as the structural damage for constructions of different building ages on the example of building types in Bucharest, Romania, resulted into compressible and interdependent charts (Bostenaru, 2003a), based on detailed studies made by the author, sometimes together with a local engineer for the World Housing Encyclopedia (EERI, 2004).

A retrofit element consists of all works which have to be done in order to strengthen, repair, rebuild or even build a structural member. Not all these are "new" building elements, like in costs index directories, and not all these are "old" building elements, like in Neddermann (2000)'s approach. Retrofit elements can be classified into: old elements, which are simply repaired elements of the existing building; new elements, which are added elements due to seismic redesign; retrofitted elements, which are old elements strengthened with new extensions and finally replaced elements, which are new elements replacing exactly the old destroyed or heavily damaged ones.

\section{Discussion}

Today's planner cannot go out from a "tabula rasa" situation any more. Environmental and sustainability issues have already formed the public idea that a "green belt" of our cities is necessary, a kind of fortification leading to intensive development of towns inside a clearly delimitated area within the 


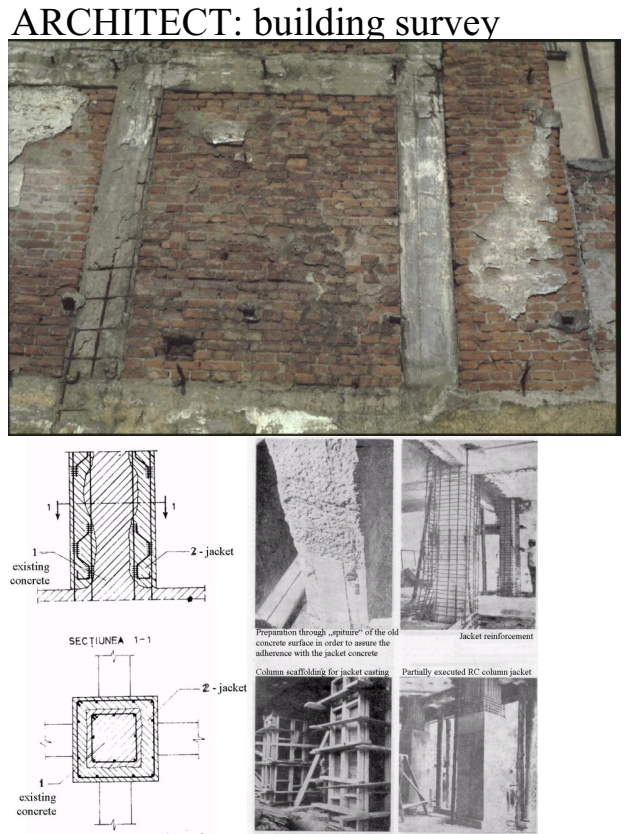

USER: project management

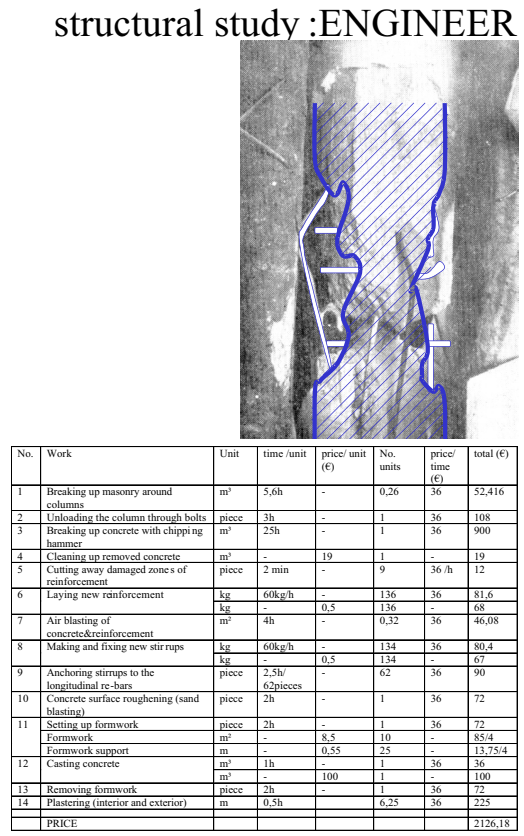

costs estimation: INVESTOR

Fig. 8. The "Retrofit element" column - a pattern at construction element scale serving the communication between actors involved in building retrofit works developed in the doctorate work of the author. In each corner an actor and his expert competence field is mentioned, along with an image visualising an activity within this. (The images on the right are based on those in the doctorate work of the author; the images on the left are based on Bostenaru (2004) while the images on top left and bottom right integrate photographs and drawings from Bãlan et al., 1982).

surrounding nature. Since building on the periphery is limited, and the existing built substance has a certain cultural, architectural or at least environmental value, upgrading existing buildings gains more and more ground from the design of new buildings. While in the majority of cases this upgrading means bringing the buildings to the comfort required by changed living standards, earthquake prone countries face a particular challenge given by the necessity to bring them also to a corresponding safety standard.

Several decision models have been analysed on their suitability for the choice of buildings to be retrofitted in urban settlements. As the group decision problem "retrofitting existing buildings" has a participative character, a historic review of participative planning models was made. What changed in the course of time are the demands to task setting, through societal changes. This is reflected particularly in housing typology, as residences have always shown the living styles. The understanding of planning, the role of the actors participating in the planning process and the instrumetarium used in implementation were the most important influence factors for these changes.

Around the concept of participation a history has developed. To mark this development, in professional literature the term "communication" started to be used instead of "participation" in order to express a characteristic of today's participation: citizens are active in the process. Communication is a collective term for intermediation works in planning comprising information, participation, co-ordination and cooperation (Selle, 1996). But communication means here more than a simple summation of these activities: while participation supposes a central decision process inside the political-administrative system, in which third parties participate within the frame of information and explanation processes, the delegation of problem solutions to the procedure accepts the existence and the relevance of independent fields outside politics and administration as well as the reality of simultaneous decision processes. Through co-operation the decision process is relocated outside. The best example that these activities have to be seen as layers not as phases is the IBA, within which historical approaches of the first as well as current strategies of the second generation are to be found one next to the other. Latest reports about the ecological city (OECD, 1996) show that procedures rich in communication in order to reach sustainability, are no happenstance, as participation is going to be an important instrument in the way thereto, just as innovation and information.

Only if the actors implied in the retrofit design process have a common language to communicate, measures packages of the retrofit strategy can be implemented successfully from pilot projects on, and the learning process which assures spreading of such demonstrations can take place. This language cannot consist of simple items but of complex spatial situations, like the patterns of Christopher Alexander. Several suitable patterns are already included in Alexander's 


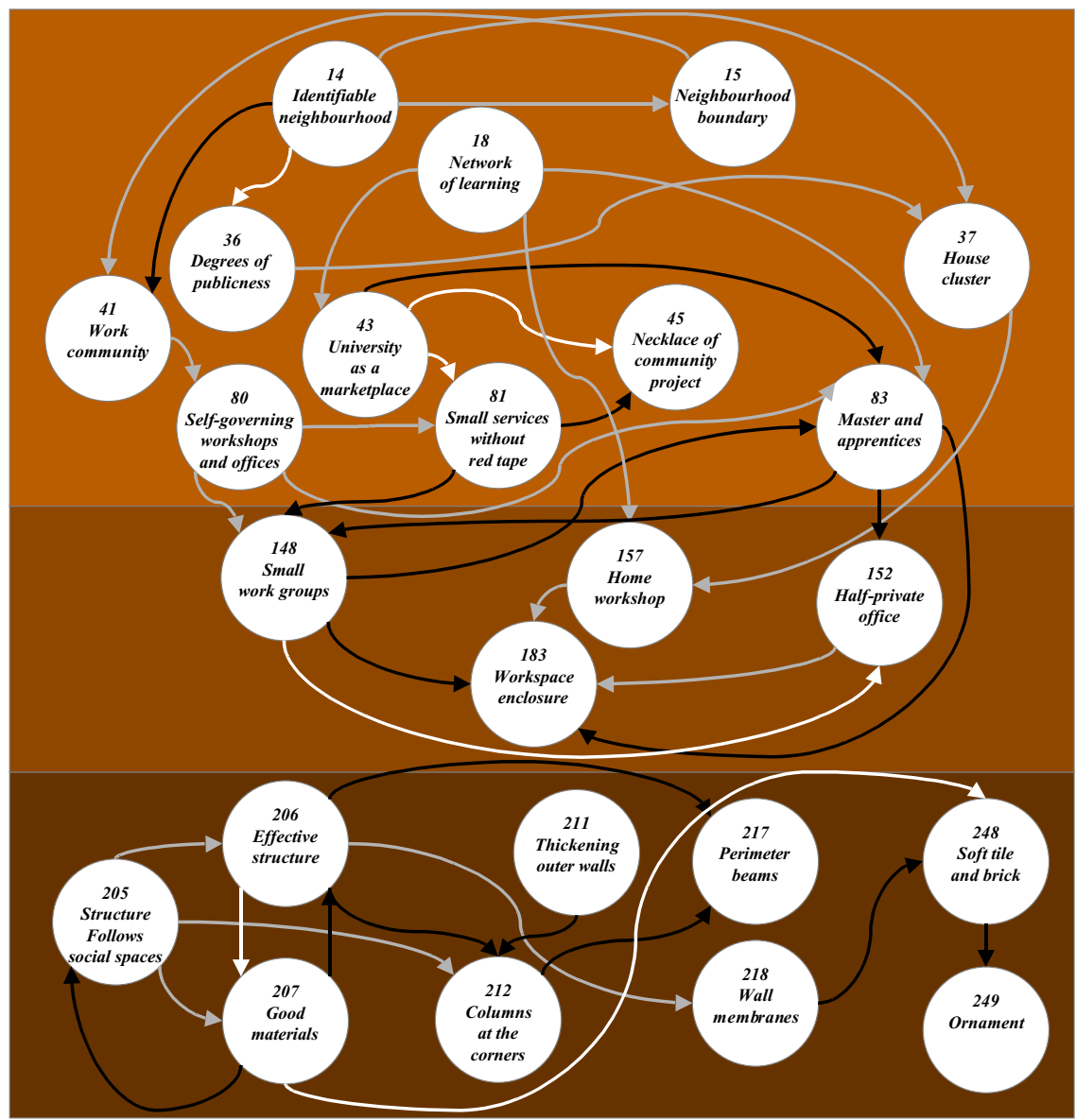

Fig. 9. Example of connection links in the "pattern language" (Alexander et al., 1977) on selected items, suitable for implementing building retrofit, based on their introductory and concluding description respectively. Provided are the number and the name of the pattern (quotation), the patterns which base on them (outgoing black arrows), the patterns on which these are based (incoming white arrows if this is not based on an outgoing relationship from the other pattern and incoming grey arrows otherwise), and the scale of the pattern (on light brown for towns, on brown for buildings and on dark brown for construction elements).

approach. They concern mainly the design of communication spaces for the actors themselves (Fig. 9). Such a pattern, "Network of learning" has been achieved at Byker, Newcastle, United Kingdom, by R. Erskine (see also Erskine, 1977). A good approach for implementing participatism for building retrofit is described by the pattern "Necklace of community project" (Fig. 1). For the side of the "experts" the pattern "Work community" seems the most suitable from the "town", and "Half-private office" from the "building" patterns. Several patterns from the "construction" part help defining another way of bringing over the view of the architect. Two of them, "Effective structure" and "Good materials", are quite subjective.

The conclusions regarding the role of the learning process in a changeable environment drawn out from the demonstration project in Hollabrunn, opened a perspective on parallel circuits. Fig. 10 shows in a diagram a parallel relationship between an "educational flow" and the implementation process of an urban measure, as well as their complex relationships involving all actors but particularly the "affected people". A supporting instrument can be a database for the presentation to the public, for navigation between urban/building level and for feedback from the programs. A successful example of such a database is the one of the World Housing Encyclopaedia. The potential for collaborative issues consists in this later case out of data sharing and information exchange, as well as of generation of charts to support decision making. The author of this paper, active participant in the project, sees an important way of development of the encyclopaedia in the transformation from an expert information system into a decision system. The World Housing Encyclopedia is right now an expert information system. It needs criteria weighting and additional criteria, as well as a negotiation tool for collaborative issues.

In ATC-40 (1996), similarly to the problematic of the upgrading of existing buildings, it can be talked of system completion, of changes in order to reach the objectives like retrofit for strengthening and stiffening, enhancing deformation capacity and finally of conservation of the building with meanwhile reducing of earthquake demands. Management 
Application circuit

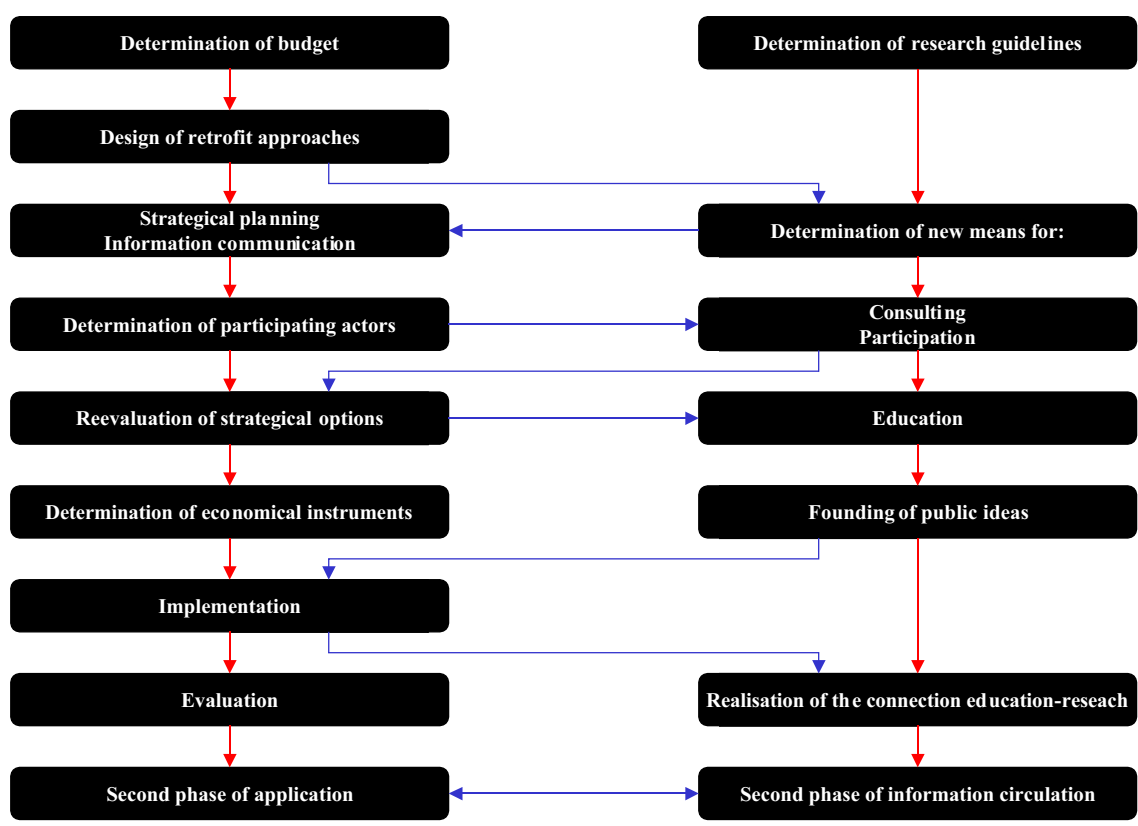

Fig. 10. Diagram showing parallel flows in the implementation circuit of the retrofit measure and the social dimension of education circuit realised hither through, as well as their interdependencies (after Bostenaru, 2002).

strategies encompass rather alternatives (options pairs) than variants, like demolition/rebuild, temporary/phased retrofit, exterior/interior retrofit, or retrofit during occupancy/of a vacant building. The criteria used to generate alternative pairs described in ATC-40 (1996) provide for the implementation of certain retrofit systems the correspondence with the criteria for the execution (construction measures for the realisation of retrofit systems) and thus of relevance for "investor" and "user" interest groups. To be noted is the transition from strategy choice to the evaluation of project efficiency in the last stages of decision technique (Fig. 5). When evaluating the efficiency, the decision problem becomes a single criterion one (like in the method described in Smyth et al., 2004), while if the chosen solution is not efficient the decision process is set back to the first stage, a multi-criteria one, where constraints have not been yet converted to the same unit of measure.

Models concerning restoration of heritage, or rehabilitation of historical existing buildings, like the ones applied by Nägele (1992) or developed by Neddermann (2000), are helpful to support the developed concept of "retrofit elements", on which the author's decision model in the doctorate thesis is based, as they establish the comparison basis between rehabilitation and retrofit projects. Correspondence exists between the elements used to define the architect's criteria and the "retrofit elements" defined from the structural point of view. More even, the material criteria are not different from those set in usual rehabilitation works, as showed by Nägele (1992). Recognition characteristics, construction works with duration and needed resources, implied costs for strengthening and reparation as well as earthquake resilient features, seismic deficiencies and earthquake damage patterns can be assigned to structural members in form of point elements (frame nodes), line elements (columns and beams) and surface elements (floors and walls). Earthquake resilient features, seismic deficiencies and earthquake damage patterns build a package called "seismic features" in a typical World Housing Encyclopedia (EERI, 2004) report. Available retrofit or strengthening methods for the typical seismic deficiencies are documented in the Encyclopaedia as well. A format similar to that proposed by Neddermann (2000) has been developed first for the strengthening works performed on a not damaged building. This implied the division of the building into entities following project management principles. For repair works the outcome from finite elements simulations was taken into account. In a stress-strain based analysis of reinforced concrete structures performance criteria for gradual concrete and steel failure in the elements have been set, from fracture of reinforcement bars together with cracking till crushing of concrete core, cracking and spalling of cover concrete to slight cracks in the concrete cover. Such cumulative damages can be associated with certain damage patterns in the respective elements, to which again corresponding repair works can be assigned, including their associated costs. The packages for strengthening works, repair works or both together form retrofit works packages. 


\section{Conclusions}

While not investigating risk perception as such, the paper addresses specifically the way to enhance the acceptance of measures towards the reduction of (seismic) risk. Research on participative aspects in decision making gives an outlook on dialogue possibilities with citizens. Building construction requires a special kind of such a dialogue compared to other sciences: citizens have been anyway always implied in the decision process through their ownership type in case of housing and are more and more through the democratisation of planning. The basis for this communication are not the results of theoretical research only, but also continued documentation of examples of best practice. It contributes to the field of sustainable development, as providing a more safe urban environment is a task undertaken in thinking at future generations. The central tasks of environmental politics cannot be justified and implemented without communication effort.

There was looked at the evolution in the last 40 years, highlighting the transition between different levels, which correspond to different amounts of participation, during the respective decades. Historical approaches like the "pattern language" proposed by Christopher Alexander in the 60s, which could provide a communication language between the actors, or the "Stichting Architects Research" method, which provided for architectural research on participation for the first time, can be seen not as phases but as layers showing the participative activation degree, just like approaches lasting till today. Such contemporary strategy examples are the rehabilitation decision model of Nägele (1992), or the ATC40 (1996) decision model for assigning each an adequate technical and an adequate management strategy to dedicated retrofit systems. The author is actively involved in some new developments, like the information sharing model in the World Housing Encyclopedia project, an expert information system which evolve to a decision support system, and the "retrofit elements" based decision approach from the doctorate work, considering similar interest groups to the models reviewed. Looking at the interdependences it resulted that the "pattern language" has the potential to be a communication language between the actors. Numerous patterns for this are already provided and the format would allow to describe the spatial situations contained in the goals of the actors in an understandable way for all of them.

Acknowledgements. The author thanks the guest editor T. Glade for the opportunity to publish. Comments from the anonymous reviewers and from the responsible editor helped in significantly improving the manuscript. Thanks go to B. Schäfers and to the editorial board of the "World Housing Encyclopedia" for the possibility to work on these research topics and respectively being part of the editorial board (voluntary effort). The financial support from the Akademisches Auslandsamt (printing allowances) for an individual study in Sociology of Architecture and from the DFG, the German Research Foundation, (three years funding for the doctorate research and further infrastructure and research expenses in frame of the GK450, as associated "Kollegiatin") are gratefully acknowledged. The help of my former student, now Dipl.-Ing., G. Öztürk, whom the author advised for the diploma work on a project management related topic, is also acknowledged. For some of the figures a student version of the software archiCAD $\AA$ from Graphisoft ${ }^{\circledR}$ was used.

Edited by: T. Glade

Reviewed by: two referees

\section{References}

Alexander, Ch., Ishikawa, S., and Silverstein, M.: A Pattern Language, Towns. Buildings. Construction, Oxford University Press, New York, 1977.

Amery, C. (criticism): The Architectural Review, Housing, Byker, Newcastle upon Tyne, Arch. Ralph Erskine, Vernon Gracie \& Associate, CLVI, 934, 346-362, 1974.

ATC-40: Seismic Evaluation and retrofit of concrete buildings, CSSC, California, 1996.

Bãlan, S., Cristescu, V., and Cornea, I. (Eds.): Cutremurul de pãmânt din România de la 4 martie 1977 = "Earthquake in Romania on 4 March 1977" (in Romanian), Academy of the Socialist Republic of Romania, Bucharest, 1982.

Behringer, L.: Leben in der Stadt - Stabilität durch soziale Einbindung = "Living in the City - Stability through Social Connection“ (in German), in: Brech, J. (Ed.): Neue Wege in der Planungskultur, Orientierungen in der Zeit des Umbruchs = "New Ways in Planning Culture, Orientation in the Times of Change“, VWP (Verlag für Wiss. Publ.), Darmstadt, 181-186, 1993.

Bohning, I.: Autonome Architektur und partizipatorisches Bauen, Zwei Architekturkonzepte = "Autonomous Architecture and Participative Construction, Two Architectural Concepts“ (in German), Birkhaeuser, Basel/Stuttgart, 1981.

Bostenaru Dan, M: Calculation of Costs for Seismic Rehabilitation of Historical Buildings, In: Brebbia, C. A. and Corz, A. (Eds.): Earthquake Resistant Engineering Structures III, WIT Press, Southampton, 515-524, 2001.

Bostenaru Dan, M.: Wirtschaftlichkeit und Umsetzbarkeit von Gebäudeverstärkungsmaßnahmen zur Erdbebenertüchtigung = "Applicability and Economic Efficiency of Seismic Retrofit Measures on Existing Buildings“ (in German), In: Tetzlaff, G., Trautmann, T., and Radtke, K.S. (Eds.): Second Forum on Catastrophy Mitigation, 128-135. DKKV, Bonn and Leipzig and www.dkkv.org/forum2001/Datei17.pdf, 2002.

Bostenaru Dan, M.: Interpreting the Photographical Information Stored in Multimedia GIS”, In: Plapp, T., Hauck, C., and Jaya, M. (Eds.): Ergebnisse aus dem interfakultativen Graduiertenkolleg Naturkatastrophen. Zusammenstellung ausgewählter Veröffentlichungen und Forschungsberichte 1998 bis $2002=$ "Results from the interdeparmental Research Training Group Nature's disasters, Compilation of selected publications and research reports 1998 till 2002“ (in German), GK 450, University of Karlsruhe, Germany, 93-105, 2003a.

Bostenaru Dan, M.: Integrated System for building survey and evaluation of seismic retrofit possibilities. In: Brebbia, C. A. (Ed.): Structural Studies, Repairs and Maintenance of Heritage Architecture VIII, WIT Press, Southampton, 555-564, 2003b.

Bostenaru Dan, M.: Early reinforced concrete frame condominium building with masonry infill walls designed for gravity loads only", Report 96-Romania, Available electronically at www. 
world-housing.net/, Earthquake Engineering Research Institute and International Association for Earthquake Engineering, 2004.

Brzev, S., Tomazevic, M., Lutman, M., Bostenaru Dan, M., D'Ayala, D., and Greene, M.: The World Housing Encyclopaedia: An online Resource on Housing Construction in High Seismic Risk Areas of the World, In: Proceedings of SE 40EEE International Conference in Earthquake Engineering to Mark 40 Years from Catastrophic Skopje Earthquake and Successful City Reconstruction, 26-29 August 2003, Skopje, FYR Macedonia, CD ROM, 2003.

EERI (Earthquake Engineering Research Institute): World Housing Encyclopedia, www.world-housing.net, 2004.

Erskine, R.: Byker Redevelopment, Newcastle upon Tyne, Großbritannien (in cooperation with V. Gracie), Bauen und Wohnen, 32, 1, 25-32 (as well as construction sheets on 21-24), 1977.

Fassbinder, H.: Das Berliner Stadtforum - Herausforderung in der Stadtentwicklung = "The Townforum Berlin - Challenge in Urban Development“ (in German). In: Brech, J. (Ed.): Neue Wege in der Planungskultur. Orientierungen in der Zeit des Umbruchs, VWP (Verlag für Wiss. Publ.), Darmstadt, 221-222, 1993.

FEMA 154: Rapid Visual Screening of Buildings for Potential Seismic Hazards: A Handbook, FEMA, Washington, D.C., 1988.

FEMA 174: Establishing Programs and Priorities for the Seismic Rehabilitation of Buildings: A Handbook, FEMA, Washington, D.C., 1989.

Fingerhuth, K. and Koch, M.: Gestaltung zwischen Entwurf und Vereinbarung. Zur Verständigung über Funktion und Ästhetik bei der Planung und Realisierung von Neubauten = Conformation between Project and Agreement. On the Understanding of Function and Aesthetics in the Planning and Realisation of New Buildings" (in German), In: Selle, Klaus (Ed.): Planung und Kommunikation = "Planning and communication" (in German), Bauverlag, Wiesbaden/Berlin, 23-40, 1996.

Freisitzer, K., Koch, R., and Uhl, O.: Mitbestimmung im Wohnbau = "Co-determination in Housing" (in German), a handbook, Picus-Verlag, Vienna, 1987.

Habraken, N. J.: Stichting Architekten Research: Industrialisierter Wohnungsbau $=$ "Stichting Architects Research: Industrialised Housing Construction“ (in German), Bauwelt, 10, 299-310, 1968.

Häußermann, H. and Siebel, W.: Wandel von Planungsaufgaben und Wandel der Planungsstrategie - Das Beispiel der IBA Emscher Park = "Change of Planning Tasks and Change of Planning Strategy, The Example of IBA Emscher Park" (in German). Arbeitskreis Stadterneuerung an Deutschsprachigen Hochschulen; Institut für Stadt- und Regionalplanung der TU Berlin: Jahrbuch Stadterneuerung 1993: Beiträge aus Lehre und Forschung an deutschsprachigen Hochschulen, 141-151, 1993

Heinz, W: Public Private Partnerships - Chancen und Grenzen öffentlich-privater Kooperation bei der Stadtentwicklung = "Public Private Partnerships - Chances and Limits of Public-Private Co-operation in Urban Development" (in German), In: Brech, J. (Ed.): Neue Wege in der Planungskultur. Orientierungen in der Zeit des Umbruchs, VWP (Verlag für Wiss. Publ.), Darmstadt, 143-148, 1993
Hempel, H. and Uhl, O.: Kooperatives Planungshandeln, partizipatorisches Bauen in einer prozessualen Architektur $=$ "Cooperative Planning Action, Participative Construction in a Processual Architecture“ (in German), Bauforum, 15, 90, 8-16, 1982.

IBA: Die Internationale Bauausstellung Emscher Park (1989-1999) $=$ "The International Construction Exhibition Emscher Park (1989-1999)“ (in German), www.iba.nrw.de, 1999.

Koenigs, T.: StadtParks, Urbane Natur in Frankfurt am Main = "CityParks, Urban Nature in Frankfurt on the Maine" (in German), Campus-Verlag, Frankfurt/Main, New York, Die Zukunft des Städtischen; 9, 1993.

Leichtle, B.: Die Ausstrahlungskraft der Idee der Gemeinschaft am Beispiel B.R.O.T. = "The Emanation Power of the Community Idea on Example B.R.O.T.“ (in German), In: Brecht, J. (Ed.): Neue Wege in der Planungskultur, Orientierungen in der Zeit des Umbruchs. VWP (Verlag für Wiss. Publ.), Darmstadt, 7377, 1993.

Lungu, D. and Saito, T. (Eds.): Earthquake Hazard and Countermeasures for Existing Fragile Buildings, Independent Film, Bucharest, 2001.

Lürssen, R. and Richters, B.: Die Erneuerung einer westdeutschen Großsiedlung - am Beispiel Bremen-Osterholz-Tenever = "The Modernisation of a Large Housing Estate in Western Germany - the Example of Bremen-Osterholz-Tenever" (in German), In: Froessler, R. (Ed.): Lokale Partnerschaften: Die Erneuerung benachteiligter Quartiere in europäischen Städten. Birkhäuser, Basel/Boston/Berlin, Stadtforschung aktuell, 45, 220-231, 1994.

Lynch, K.: The Image of the City, MIT Press, Cambridge MA/London, 2000 (27th edition; first edition 1960).

Malczewski, J.: GIS and Multicriteria Decision Analysis, John Wiley\&Sons, New York, 1999.

Nägele, H.: Die Restaurierung der Weißenhofsiedlung 1981-1987 = "The Restoration of the Weißenhof Siedlung 198-1987" (in German), Karl Krämer, Stuttgart, 1992.

Neddermann, R.: Kostenermittlung in der Altbauerneuerung und technische Beurteilung von Altbauten = "Costs Calculation in Rehabilitation of Existing Buildings and Technical Assessment of Existing Buildings“ (in German), Werner, Düsseldorf, (second edition), 2000.

OECD: Final Report on the Ecological City, 1996.

Schäfers, B.: Architektursoziologie: Grundlagen, Epochen, Themen $=$ "Sociology of Architecture: Basics, Epochs, Themes" (in German), Leske \& Budrich, Opladen, 2003.

Selle, K.: Was ist bloß mit der Planung los? = "What Happened Merely to Planning i' (in German), IRPUD, Dortmund, 1994.

Selle, K. (Ed.): Planung und Kommunikation = "Planning and Communication“ (in German), Bauverlag, Wiesbaden/Berlin, 1996.

Sieverts, T. (Ed.): IBA Emscher-Park, Zukunftswerkstatt für Industrieregionen = "IBA Emscher-Park, Workshop of the Future for Industrial Regions“ (in German), Müller, Köln, 1991, (arcus; 13)

Smyth, A. W., Altay, G., Deodatis, G., Erdik, M., Franco, G., Gülkan, P., Kunreuther, H., Lu, H., Mete, E., Seeber, N., and Yüzügüllü, Ö.: Probabilistic Benefit-Cost Analysis for Earthquake Damage Mitigation: Evaluating Measures for Apartment Houses in Turkey, Earthquake Spectra, 20, 1, 171-203, 2004. 